\title{
Plasma membrane phospholipid content in non-insulin-dependent streptozotocin-diabetic rats - effect of insulin
}

\author{
J. Levy' ${ }^{1}$, Y.Suzuki ${ }^{1}$, L.V. Avioli', G. Grunberger ${ }^{3}$ and J. R. Gavin, III ${ }^{2}$ \\ Endocrinology and Bone Metabolism Division, The Jewish Hospital, \\ 2 Division of Metabolism, Washington University School of Medicine, St. Louis, Missouri, and \\ ${ }^{3}$ Diabetes Section, Department of Internal Medicine, Wayne State University School of Medicine, Detroit, Michigan, USA
}

\begin{abstract}
Summary. The activity of $\left(\mathrm{Ca}^{2-}+\mathrm{Mg}^{2+}\right)$-ATPase is impaired in kidney basolateral membranes from non-insulin-dependent streptozotocin-diabetic rats. To study the possible role of changes in membrane phospholipid content in the malfunction of this enzyme in kidney membranes of the diabetic animals, phospholipid (phosphatidic acid, phosphatidylcholine, phosphatidylethanolamine, phosphatidylinositol, phosphatidylserine, and sphingomyelin) content was measured in kidney and liver membranes obtained from non-insulin-dependent diabetic rats. Total phospholipid content was similar in liver and kidney membranes of diabetic and control rats ( $595 \pm 47$ versus $624 \pm 29$ in liver and $469 \pm 22$ versus $458 \pm$ $17 \mathrm{nmol} \mathrm{Pi} / \mathrm{mg}$ protein in kidney respectively). Phosphatidylethanolamine content in kidney and liver membranes of diabetic rats was lower than in control rats $(87.7 \pm 1.8$ versus $96.4 \pm 2.2 \mathrm{nmol} \mathrm{Pi} / \mathrm{mg}$ protein, $p<0.01$ and $87.1 \pm 3.7$ versus $101.8 \pm 3.5, p<0.02$ respectively). Phosphatidylinositol content was higher in kidney $(28.0 \pm 0.6$ versus $23.9 \pm 2.1, p<$ 0.02 ) but not liver membranes from diabetic rats.
\end{abstract}

The in vitro direct effect of insulin on the phospholipid content in kidney membranes was also measured. Physiologic concentrations of insulin $(718 \mathrm{pmol} / 1$ for $30 \mathrm{~min})$ increased the phosphatidic acid content in membranes from control but not from diabetic rats by $34.2 \%(p<0.02)$. This rise was readily measurable after $3 \mathrm{~min}$ of exposure to insulin. Insulin did not induce a significant change in the content of any other phospholipid in membranes from control or diabetic rats.

These differences in phospholipid content demonstrated in isolated membranes obtained from non-insulin-dependent diabetic and control rats, before and after exposure to insulin, may explain, in part, the impaired function of the $\left(\mathrm{Ca}^{2+}+\mathrm{Mg}^{2+}\right)$-ATPase observed previously in kidney membranes of the diabetic rats.

Key words: Phospholipids, membrane, diabetes, insulin.
A variety of polypeptide hormones can provoke rapid changes in phospholipid metabolism in their target tissues [1-7]. Insulin acutely increases phospholipids in the phosphatidate-inositide cycle in rat adipose tissue both in vivo and in vitro $[2,8]$. Shifts in membrane phospholipid content may be important in regulating the activity of a variety of cellular enzymes, including those which control intracellular $\mathrm{Ca}^{2+}$ homeostasis. In this regard, purified $\left(\mathrm{Ca}^{2+}+\mathrm{Mg}^{2+}\right)$-ATPase can be regulated by a variety of acidic phospholipids [9]. Since it is clear that this enzyme requires phospholipids for its activity within the plasma membrane [10, 11], changes in membrane phospholipid content would be expected to affect its activity.

Neonatal rats rendered diabetic by streptozotocin (STZ) injection develop non-insulin-dependent diabetes and have impaired peripheral insulin action in vivo and in vitro [12-15]. We have shown that exposure to physiologic concentrations of insulin increased the $\left(\mathrm{Ca}^{2+}+\mathrm{Mg}^{2+}\right)$-ATPase activity in kidney basolateral membranes (BLM) obtained from normal dogs and rats $[16,17]$. However, in BLM obtained from the diabetic rats the basal $\left(\mathrm{Ca}^{2+}+\mathrm{Mg}^{2+}\right)$-ATPase activity was higher than in control rats and failed to respond to insulin in vitro [16].

We propose that changes in plasma membrane phospholipid composition may play a significant role in the impairment of $\left(\mathrm{Ca}^{2+}+\mathrm{Mg}^{2+}\right)$-ATPase activity observed in BLM of diabetic rats [16]. To investigate this possibility, we have studied phospholipid content in kidney BLM obtained from control and diabetic rats as well as the direct in vitro effect of insulin on phospholipid content of these membranes. In order to assess whether changes in membrane phospholipid composition in diabetic rats are limited to kidney BLM, we have also evaluated the composition of phos- 
pholipid content in liver membranes obtained from these non-insulin-dependent diabetic and control rats.

\section{Materials and methods}

Two-day-old Sprague-Dawley rat pups were injected i.p. with $90 \mathrm{mg} / \mathrm{kg}$ body weight STZ (Ujpjohn Co., Kalamazoo, Mich, USA) in $0.1 \mathrm{~mol} / 1$ citrate buffer, $\mathrm{pH} 4.5$ according to previously described methods [14-16]. At 4 days of age $0.1 \mathrm{ml}$ of blood was collected into heparinised capillary tubes by cardiac puncture and plasma glucose was measured by the glucose-oxidase method. Animals that demonstrated plasma glucose levels of $11.2 \mathrm{nmol} / 1$ or above were selected as diabetic $[12,18]$. The animals were weaned at 24 days of age and separated according to sex. Only male rats were used in this study. The rats were kept at 4-5 animals per cage, exposed to 10-h on, 14-h off light cycles and were allowed to feed ad libitum on standard rat laboratory chow (Purina 5001). At age 11 weeks the animals were weighed and then killed by decapitation. The animals were in the non-fasting state and all decapitations were performed between $09.00-11.00$ hours. To minimizc the effect of time of killing on the results, diabetic and control animals were killed in random order until all the animals were used.

Blood specimens were collected from the decapitated rats directly into heparinised $50 \mathrm{ml}$ plastic tubes and after separation the plasma was kept frozen at $-20^{\circ} \mathrm{C}$ for glucose and insulin determinations. The livers and kidneys were immediately separated, weighed and kept on ice for membrane preparations.

\section{Membrane preparations}

Suspensions enriched for kidney BLM originating from kidney cortical mince were prepared according to the method of Sacktor et al. [19] using a Percoll gradient ultracentrifugation [20]. The final two centrifugations of the preparative procedure for BLM preparation were performed using a $0.25 \mathrm{~mol} / 1$ sucrose, $10 \mathrm{mmol} / 1 \mathrm{MnCl}_{2}$, $50 \mathrm{mmol} / \mathrm{l}$ Tris $\mathrm{HCl}$, pH 7.5 solution [16]. Ten different membranes were prepared from each group (diabetic rats and controls); kidneys from 7-8 animals were used for each membrane preparation. Liver membranes were preparcd from 6 different individual animals (diabetic rats and controls) using the method of Tsushima and Friesen [21]. Protein determination was done by the method of Lowry [22]. After preparation the membranes were separated into aliquots containing $1 \mathrm{mg}$ protein samples and kept frozen at $-70^{\circ} \mathrm{C}$ until phospholipid measurements were performed. As previously described in detail [16], these kidney BLM membranes show 10-11-fold enrichment in the plasma membrane marker, $\left(\mathrm{Na}^{+}+\mathrm{K}^{+}\right)$-ATPase compared to homogenates. Membranes from the diabetic and control animals had the same degree of purification.

Glucose was measured using the Beckman Glucoanalyzer II (Beckman Instruments, Fullerton, Calif, USA) [23]. Insulin was determined by the radioimmunoassay method of Morgan and Lazarow [24]. Coefficient of variation of the technique was $6.5 \%$.

\section{In vitro hormone treatment}

$1.5 \mathrm{mg}$ protein of kidney BLM obtained from control and diabetic rats were incubated in a medium containing $5.5 \mathrm{mmol} / 1$ glucose, $2 \mu \mathrm{mol} / 1 \mathrm{Ca}^{2-}[16], 120 \mathrm{mmol} / 1$ Tris $\mathrm{HCl}, \mathrm{pH} 7.2$, at $37^{\circ} \mathrm{C}$, with and without insulin $(718 \mathrm{pmol} / 1)$. Incubation time was $30 \mathrm{~min}$ unless otherwise specified. Incubation was terminated by addition of ice cold chloroform-methanol solution $(1: 2 \mathrm{v} / \mathrm{v})$ and phospholipids were immediately extracted and measured.

\section{Phospholipid determination}

Membrane phospholipids were extracted by the method of Bligh \& Dyer [25]. The final chloroform lipid phase was stored under $N_{2}$ at $-80^{\circ} \mathrm{C}$ in microvials, coated with Glass Treet (Alltech Associates, Inc., Deerfield, Ill, USA). The extract was evaporated under a stream of $N_{2}$ and resuspended in $100 \mathrm{ul}$ of chloroform: methanol (1:1) and subjected to thin layer chromatography. For one dimensional separation, samples were spotted on pre-coated Silica-Gel 60 plate (E. Merck, Darmstadt, FRG) and chromatographed in chloroform: methanol:acetic acid:distilled water $(100: 30: 35: 3, \mathrm{v} / \mathrm{v})$. This solvent system separates sphingomyelin (Spm), phosphatidylcholine (PC), phosphatidylinositol (PI), phosphatidylserine (PS), phosphatidylethanolamine (PE), phosphatidic acid (PA), and cardiolipin (RF) values approximately $0.08,0.17,0.33,0.44,0.60,0.85$, and 0.90 , respectively [26]. For two dimensional separations, two different solvent solutions were used. The first solvent system consisted of chloroform:methanol:concentrated ammonium hydroxide $(15 \mathrm{~mol} / \mathrm{l})$ : water $(65: 35: 5: 0.6, \mathrm{v} / \mathrm{v})$ while the second solvent system comprised chloroform: methanol:glacial acetic acid: water $(80: 24$ : $38: 3.5, \mathrm{v} / \mathrm{v})$. After development, the plates were dried and phospholipid spots were visualised by iodine vapor and identified by comparison to migration of authentic standards (Sigma Chemical, St. Louis, MO, USA). The spots were scraped from the plates and digested in $10 \mathrm{~N} \mathrm{H}_{2} \mathrm{SO}_{4}$ for $3 \mathrm{~h}$ at $160^{\circ} \mathrm{C}$. Then 4 drops of $30 \%$ hydrogen peroxide were added and samples were reheated for $1.5 \mathrm{~h}$ at $160^{\circ} \mathrm{C}$. Phosphorus content of the digest was determined by the method of Bartlett [27]. The membrane phospholipid content was expressed as $\mathrm{nmol} \mathrm{Pi} / \mathrm{mg}$ protein. Total lipid phosphorus was determined directly from the lipid extract by the method described above, and results were calculated as $\mathrm{nmol} \mathrm{Pi} / \mathrm{mg}$ protein. Two dimensional chromatography for separation of the phospholipids was used in the incubation studies to assure that contamination with new phospholipid metabolites did not influence the measurements of the phospholipids of interest in this study. All phospholipid assays were done in duplicates.

\section{Statistical analysis}

Results were expressed as mean \pm SEM. Statistics for the determination of the membrane phospholipid content were performed using two tailed $t$-test. Results from the incubation experiments were analysed using Student's paired t-test, since direct comparisons were made on the same membrane preparations under identical conditions except for the presence of insulin.

\section{Results}

The characteristics of the diabetic and control animals used for the liver and kidney membranes preparations are given separately in Tables 1 and 2, respectively, since two separate paired groups of animals were used for these procedures. The weight of the diabetic animals at the time of killing was lower by $9 \%$ compared to control rats for both sets of animals $(p<0.05$ and

Table 1. Rats used for liver membrane preparations

\begin{tabular}{lllll}
\hline & $\begin{array}{l}\text { Glucose } \\
(\mathrm{mmol} / \mathrm{l})\end{array}$ & $\begin{array}{l}\text { Insulin } \\
(\mathrm{pmol} / \mathrm{l})\end{array}$ & $\begin{array}{l}\text { Body weight } \\
(\mathrm{g})\end{array}$ & $\begin{array}{l}\text { Liver weight } \\
(\% \text { of } \\
\text { body weight })\end{array}$ \\
\hline $\begin{array}{l}\text { Control } \\
\text { rats (6) }\end{array}$ & $7.84 \pm 0.17$ & $120.6 \pm 8.9$ & $229.3 \pm 7.1$ & $5.5 \pm 0.5$ \\
$\begin{array}{l}\text { Diabetic } \\
\text { rats (6) }\end{array}$ & $10.30 \pm 0.73^{\mathrm{b}}$ & $143.6 \pm 0.73$ & $199.0 \pm 10.6^{\mathrm{a}}$ & $5.3 \pm 0.3$ \\
\hline
\end{tabular}

Results are given as mean \pm SHM. The number of rats is given in parentheses. ${ }^{a} p<0.05 ;{ }^{\circ} p<0.01$ diabetic versus control rats 
$p<0.001$, respectively). There was no difference in the kidney or liver weight between the diabetic and control rats when these values were expressed as percentage of total body weight (Tables 1 and 2).

There was no difference between the diabetic and control rats in the random plasma insulin values. Nonfasting plasma glucose values obtained at the same time were significantly higher in the diabetic rats $(p<$ $0.01-p<0.001)$. The lack of difference in plasma insulin values between the diabetic and control animals is consistent with our previous report [19] where the random plasma insulin levels of the diabetic rats were only slightly decreased and averaged $73 \%$ of the control rats.

The results describing the phospholipid content in kidney BLM from the diabetic and control animals are given in Table 3. BLM obtained from the diabetic rats revealed significantly higher PI content and lower PE content $(p<0.02$ and $p<0.01$, respectively). In addition, the crude liver membranes obtained from the dia-

Table 2. Rats used for kidney basolateral preparations

\begin{tabular}{lllll}
\hline & $\begin{array}{l}\text { Glucose } \\
(\mathrm{mmol} / \mathrm{l})\end{array}$ & $\begin{array}{l}\text { Insulin } \\
(\mathrm{pmol} / \mathrm{l})\end{array}$ & $\begin{array}{l}\text { Body } \\
\text { weight } \\
(\mathrm{g})\end{array}$ & $\begin{array}{l}\text { Kidney } \\
\text { weight } \\
(\% \text { of } \\
\text { body } \\
\text { weight })\end{array}$ \\
\hline $\begin{array}{l}\text { Control } \\
\text { rats (64) }\end{array}$ & $7.84 \pm 0.11$ & $155.1 \pm 16.7$ & $232 \pm 6$ & $0.74 \pm 0.2$ \\
$\begin{array}{l}\text { Diabetic } \\
\text { rats (61) }\end{array}$ & $11.25 \pm 0.67^{\mathrm{b}}$ & $143.6 \pm 10.8$ & $212 \pm 4^{4}$ & $0.74 \pm 0.3$ \\
\hline
\end{tabular}

Results are given as mean $\pm S E M$. The number of animals is given in parentheses. ${ }^{\mathrm{a}} p<0.02 ;{ }^{\mathrm{b}} p<0.001$ diabetic versus control rats betic rats also revealed a lower PE content (Table 4). There was a marked overall difference in the phospholipid content of the liver membranes compared to that of the kidney BLM (Tables 3 and 4). Total phospholipid content of the liver membranes and kidney BLM obtained from control rats was not different from that in the membranes obtained from the diabetic animals $(595 \pm 47$ vs $624 \pm 29$ and $469 \pm 22$ vs $458 \pm 17 \mathrm{nmol}$ $\mathrm{Pi} / \mathrm{mg}$ protein respectively).

The effects of in vitro insulin treatment of BLM on phospholipid content were then examined. The incubation conditions by themselves did not result in a significant change in total phospholipid content. The levels found before and after incubations in the absence of insulin were $469 \pm 22$ vs $448 \pm 37$ for control rats and $458 \pm 17$ vs $478 \pm 49 \mathrm{nmol} \mathrm{Pi} / \mathrm{mg}$ protein for diabetic rats respectively. After incubation of the membranes, the difference in PI and PE content between BLM of control and diabetic rats did not reach significance, possibly due to increased variability (and SEM) in the phospholipid values of the incubated membranes.

Upon addition of insulin to the in vitro incubations no significant changes in total phospholipid content of BLM were noted for control $(452 \pm 37 \mathrm{nmol} \mathrm{Pi} / \mathrm{mg}$ protein) or for diabetic rats $(487 \pm 56 \mathrm{nmol} \mathrm{Pi} / \mathrm{mg}$ protein). However, there was a measurable effect of insulin on PA content in BLM of control rats (Table 5). This effect was time-dependent. After a 3-min incubation of control BLM with physiological concentrations of insulin $(718 \mathrm{pmol} / \mathrm{l})$, there was a $26.7 \pm 5.5 \%$ increase in PA, which progressed to $32.0 \pm 6.7$ by $10 \mathrm{~min}$ and remained elevated for $30 \mathrm{~min}$ (Table 6). By $60 \mathrm{~min}$, PA levels had returned to baseline. Insulin did not change significantly the content of the other phospholipids measured (PE, PS, PI, PC, Spm) in membranes

Table 3. Phospholipid composition in kidney basolateral membranes of diabetic and control rats

\begin{tabular}{lllllll}
\hline & \multicolumn{4}{l}{ Phospholipids } & & \\
\cline { 2 - 6 } & PA & PE & PS & PI & PC & Spm \\
& (nmol Pi/mg protein) & & & $138.9 \pm 6.9$ & $75.4 \pm 1.8$ \\
Diabetic rats (8) & $8.02 \pm 0.6$ & $87.7 \pm 1.8^{\mathrm{b}}$ & $38.2 \pm 3.1$ & $28.0 \pm 0.6^{\mathrm{a}}$ & $136.9 \pm 5.9$ \\
Control rats (8) & $8.1 \pm 0.6$ & $96.4 \pm 2.2$ & $36.7 \pm 2.1$ & $23.9 \pm 2.1$ & $74.7 \pm 2.4$ \\
\hline
\end{tabular}

PA - phosphatidic acid; PE - phosphatidylethanolamine; PS .. phosphatidylserine; PI - phosphatidylinositol: Spm - sphingomyelin; PC phosphatidylcholine. Numbers in parentheses refer to number of membranes used. Each membrane preparation was from $7-8$ animals. Results are given as mean \pm SEM. Statistics were done using two tailed t-test. ${ }^{a} p<0.02 ;{ }^{b} p<0.01$ diabetic versus control rats

Table 4. Phospholipid composition in liver membranes of diabetic and control rats

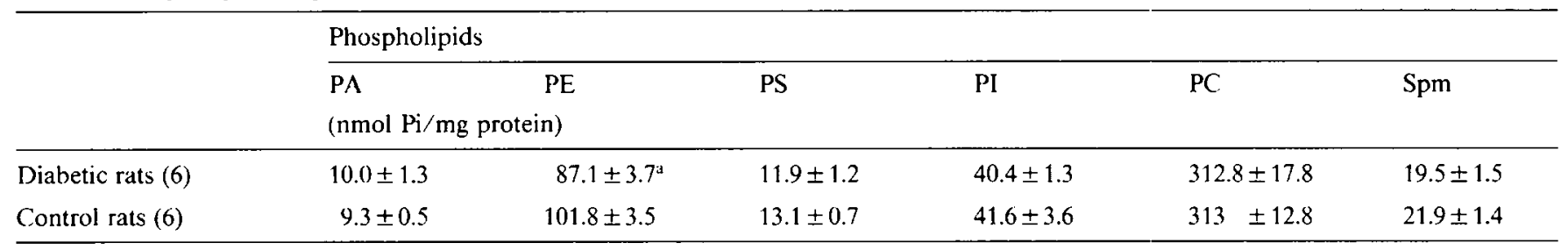

The numbers in parentheses refer to the number of membranes used. Results are given as mean \pm SEM. Statistics were done using two tailed t-test. ${ }^{a} p<0.02$ 
Table 5. Effect of insulin on phospholipid composition in kidney basolateral membranes from diabetic and control rats

\begin{tabular}{|c|c|c|c|c|c|c|}
\hline & \multicolumn{6}{|c|}{ Phospholipids } \\
\hline BLM of diabetic rats in presence of insulin (10) & $7.0 \pm 0.6$ & $92.3 \pm 7.2$ & $37.4 \pm 4.4$ & $28.2 \pm 3.6$ & $151.0 \pm 9.8$ & $69.3 \pm 7.6$ \\
\hline BLM of diabetic rats in absence of insulin (10) & $6.9 \pm 0.5$ & $91.3 \pm 5.3$ & $37.0 \pm 3.4$ & $28.06 \pm 2.6$ & $153.7 \pm 11.4$ & $72.5 \pm 6.1$ \\
\hline BLM of control rats in presence of insulin (10) & $8.2 \pm 0.6^{a}$ & $96.9 \pm 5.1$ & $33.2 \pm 5.1$ & $24.7 \pm 3.7$ & $139.5 \pm 8.5$ & $68.0 \pm 6.8$ \\
\hline
\end{tabular}

Basolateral membranes - BLM incubation time was 30 min. Numbers in parentheses are number of membranes used. Fach membrane preparation was from 7-8 animals. Results are given as mean \pm SEM. Comparison was done between membranes (from diabetic and control rats) incubated with and without insulin. Statistics were done using paired Student's t-test ${ }^{a} p<0.02$ versus values of membranes from control rats in the absence of insulin

Table 6. Insulin-induced changes in phosphatidic acid content with time in kidney basolateral membranes of control and diabetic rats

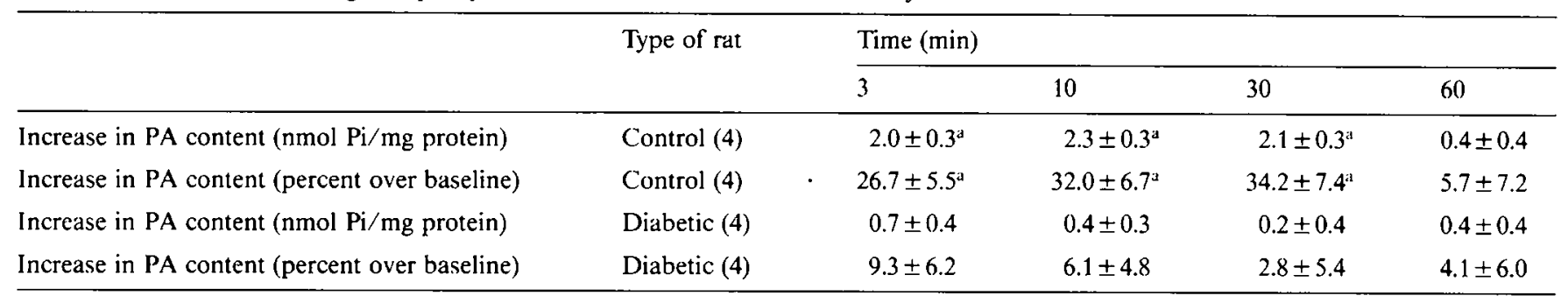

Increase $=$ difference in PA content in presence and absence of insulin in the incubation medium. Baseline $=$ PA content in the absence of insulin. Comparison was done between increases in PA content in membranes of control and diabctic rats using two-tailed t-test. Number of membranes used is indicated in parentheses. Results are given as mean \pm SEM. ${ }^{d} p<0.05$ when increases in PA content in control rat membranes are compared to increases in PA in membranes of diabetic rats

from both diabetic and control animals, either after 30 min (Table 5) or after 3,10 and 60 min of incubation (data not shown). In membranes from diabetic rats no significant insulin effect on PA content was observed either after $30 \mathrm{~min}$ (Table 5) or after any of the other time point studied (Table 6). In membranes from control rats only, total PA content in the presence of insulin was higher than those in the absence of the hormone at all time points $(p<0.02-p<0.05$ when evaluated by paired Student's t-test). Data for $30 \mathrm{~min}$ only are given in Table 5.

\section{Discussion}

Abnormal $\left(\mathrm{Ca}^{2+}+\mathrm{Mg}^{2+}\right)$-ATPase activity in membranes from non-insulin-dependent diabetic rats has been suggested as contributing to the impaired insulin action seen in these animals $[12,13,16]$. Liver and kidney cells contain specific insulin receptors [28-31], $\left(\mathrm{Ca}^{2+}+\mathrm{Mg}^{2+}\right)$-ATPase activity $[16,32]$ and are known sites for insulin action [33, 34]. Therefore, plasma membranes obtained from these tissues were studied to investigate a possible role of membrane phospholipid in the abnormal activity of $\left(\mathrm{Ca}^{2+}+\mathrm{Mg}^{2+}\right)$-ATPase in the diabetic rats. Liver and kidney membranes obtained from the diabetic animals revealed decreased PE content. Increased PI content was seen only in kidney BLM from the diabetic rats. These observations and the different overall pattern of the phospholipids in liver and kidney membranes (Tables 3 and 4) reveal that there is a tissue difference in the membrane phospholipid content. However, the diabetic state was associated with at least one change in the phospholipid content of plasma membranes common to both tissues, a relative decrease in PE. This change could not be attributed to a difference in diet between the two groups of animals since both were fed the same rodent chow and have been shown to consume the same amount of food [18].

Sauerheber et al. [35], who studied membrane lipid structure in adipocytes from control and STZ-treated diabetic rats using spin label techniques, could not show a difference between the two animal groups. This finding led the authors to conclude that no gross alteration in the membrane lipid structure occurred in cells from diabetic animals. However, the authors admitted that regional changes in membrane lipid composition could exist which they would not be able to detect by their technique. Thus, the small but significant changes observed by us using isolation and separation techniques could easily be missed. The magnitude of difference in PE and PI content in membranes from the diabetic rats compared with their controls is similar to that reported earlier in platelet membranes of diabetic patients and control subjects [36]. In that study, membranes from diabetic patients differed from control subjects in their PS and PE content. Expressed as per- 
centage of total phospholipid, membrane PS and PE contents were $5.5 \pm 0.7$ (mean $\pm \mathrm{SD}$ ) vs $6.3 \pm 0.5$ (PS) and $27.2 \pm 2.7$ vs $29.2 \pm 3.0$ (PE) in control subjects and diabetic patients respectively. These differences were highly significant $(p<0.001$ and $p<0.01)$. This magnitude of difference suggests that the disease condition is associated with only a small change in phospholipid content, affecting mainly those phospholipids which predominate the inner half of the membrane lipid bilayer, PE, PS, PI [37, 38].

According to the proposed scheme of Carafoli [39], the $\left(\mathrm{Ca}^{2+}+\mathrm{Mg}^{2+}\right)$-ATPase molecule is so oriented that its active part is on the inner side of the membrane. It is the immediate phospholipid milieu surrounding the $\left(\mathrm{Ca}^{2+}+\mathrm{Mg}^{2+}\right)$-ATPase molecule that exerts the greatest influence on the enzyme activity [10]. Thus, the different PE and PI content in BLM of the non-insulin-dependent animals could account for the abnormal $\left(\mathrm{Ca}^{2+}+\mathrm{Mg}^{2+}\right)$-ATPase activity in these membranes [16], and a corresponding lack of insulinregulated enzyme activity. Recently, Wali et al. [40] reported increased accessibility of PE and PS to phospholipase $\mathrm{A}_{2}$ of erythrocytes of diabetic patients. The authors suggested that loss of the asymmetry in distribution of phospholipids between the inner and outer membrane layers could account for this pathology. Whether similar changes occur in the BLM of the diabetic rats and further magnify the effect of the change observed in their PI and PE contents remains to be determined.

Of special interest is the finding that insulin induced a significant increment (approximately 33\%) in PA content only in membranes from control rats with no effects noted in BLM from diabetic rats (Table 5 and 6). Acidic phospholipids increase $\left(\mathrm{Ca}^{2+}+\right.$ $\mathrm{Mg}^{2+}$ )-ATPase activity [9]. Consequently, it is possible that the increase in PA content in membranes from control rats could mediate the stimulating effect of insulin on the enzyme activity $[16,17]$. Similarly, a lack of increase in PA in membranes from the diabetic rats may be important in explaining the lack of regulatory effect of the hormone on $\left(\mathrm{Ca}^{2+}+\mathrm{Mg}^{2+}\right)$-ATPase in membranes from the diabetic rats [16]. The currently described changes in membrane PA content induced by insulin are much smaller than those previously used by Niggli et al. [9] to induce an increase in the activity of the enzyme. However, while in that study a purified enzyme embedded in an artificial micelles of Triton X100 and phosphatidylcholine was studied, our observations of insulin-induced increase in both the $\left(\mathrm{Ca}^{2+}+\mathrm{Mg}^{2+}\right)$-ATPase activity [16] and PA content occurred in intact membranes. It is, therefore, possible that under more physiologic conditions (intact membranes) much smaller quantities of acidic phospholipids are sufficient to increase the enzyme activity. Furthermore, in the study of Niggli the increases in the ATPase activity induced by acidic phospholipids were up to $200-400 \%$ over basal while insulin-increase in the enzyme activity in control membranes previously observed by us was in the range of $30-35 \%$ over basal [16]. Thus, it is possible that the currently observed insulin-induced changes in PA content could explain, in part, its regulatory effect on the enzyme.

The cause for the lack of effect of insulin on PA content in membranes of diabetic animals is not clear. Insulin binding is not decreased in BLM of diabetic rats [16]. Thus, the lack of insulin effect on PA content in these membranes cannot be attributed to decreased insulin binding to its receptor. It is possible that more complex redistribution of the different phospholipids in the membrane bilayers occurs in the membranes of the diabetic rats [40]. As a result of this redistribution and the observed changes in phospholipid content, insulin might lose its ability to increase the PA content in these membranes.

The sequence of events suggested by our results predicts that insulin-induced changes in phospholipids precede the changes in $\left(\mathrm{Ca}^{2+}+\mathrm{Mg}^{2+}\right)$-ATPase activity induced by the hormone. In the current study insulin had already increased PA content in control membranes $(27 \%)$ after $3 \mathrm{~min}$ (Table 6). In fact, it is likely that these changes start even earlier. Recently, it was reported that insulin induced a $20 \%$ increase in PA content in $\mathrm{BC} 3 \mathrm{Hl}$ myocytes after only $30 \mathrm{~s}$ [41]. Therefore, the rise in the membrane PA content could conceivably mediate the stimulatory effect of insulin on $\left(\mathrm{Ca}^{2--}+\mathrm{Mg}^{2+}\right)$-ATPase activity. After $60 \mathrm{~min}$, the insulin-induced increase in membrane PA disappeared and PA content returned to baseline. Whether this occurred by direct conversion of PA into diacylglycerol as recently suggested to occur in myocytes [42], cannot be answered since diacylglycerol was not measured.

The mechanism by which insulin caused the in crease in membrane PA remains unclear, although a very likely site of such action is at the level of plasma membrane phospholipase activity. While a direct effect of insulin on membrane phospholipase was not demonstrated, this must be considered a strong possibility. The increase in PA content was not accompanied by a detectable decrease in any other specific phospholipid. This suggests that more than one phospholipid precursor contributed to the increase in membrane PA, as would occur by phospholipase D action.

Phospholipase D activity was demonstrated in several rat tissues including kidney [43]. Further, it has been suggested that the insulin-mediated increase in PA content in myocytes could be generated directly by phospholipase D [41]. Studies designed to investigate a direct regulatory effect of insulin on phospholipase D activity are needed to confirm this possibility.

The possibility that the changes observed in $\left(\mathrm{Ca}^{2+}+\mathrm{Mg}^{2+}\right)$-ATPase activity [16] and membrane phospholipid content in BLM of diabetic rats were due to toxic effects of STZ can be raised. However, several lines of evidence argue against it. These include: 1) In the diabetic animals kidney function and histology 
were shown to be normal [18] and the activity of another ATPase, $\left(\mathrm{Na}^{+}+\mathrm{K}^{+}\right)$-ATPase, in their kidney BLM is not altered [44]; 2) The previously described loss of ability of insulin to regulate the $\left(\mathrm{Ca}^{2+}+\mathrm{Mg}^{2+}\right)$-ATPase activity in kidney BLM of diabetic rats could be reversed by physiologic perturbation (submitting the animals to an 18-h food restriction) [45]; 3) Abnormalities in $\left(\mathrm{Ca}^{2+}+\mathrm{Mg}^{2+}\right)$-ATPase were recently observed by us in erythrocyte membranes of diabetic animals (unpublished data) and by others [46], in erythrocytes of diabetic patients [46] revealing that the defect in this enzyme activity in diabetes is not restricted to kidney tissue and can occur in the absence of STZ; 4) Similar to our observations, alterations in membrane phospholipids content and behaviour (specifically PE) were described also in erythrocytes and platelets of diabetic patients $[36,40]$. Taken together, it appears that the possibility that our observations in the diabetic animals are due to toxic effects of STZ is unlikely.

In conclusion, the present study reveals that BLM from non-insulin-dependent streptozotocin-diabetic rats have abnormal phospholipid content which could account for their impaired $\left(\mathrm{Ca}^{2+}+\mathrm{Mg}^{2+}\right)$-ATPase activity. Insulin specifically increases PA content only in normal rat kidney BLM, but not in membranes from the diabetic rats. It is suggested that the acute increase in this acidic phospholipid could explain in part the previously documented stimulatory effect of the hormone on membrane $\left(\mathrm{Ca}^{2+}+\mathrm{Mg}^{2+}\right)$-ATPase only in control rats. The precise mechanism by which insulin induces the increase in membrane PA content remains to be investigated.

Acknowledgements. This work was supported by research grants AM20579, AM27600, and AM32087 and by a Research and Career Development Award from the American Diabetes Association.

\section{References}

1. Farese RV, Larson RE, Sabir MA (1982) Insulin acutely increases phospholipids in the phosphatidate-inositide cycle in rat adipose tissue. J Biol Chem 257: 4042-4045

2. Farese RV, Sabir MA, Larson RE, Trudeau WL III (1983) Insulin treatment acutely increases the concentrations of phosphatidylserine in rat adipose tissue. Biochem Biophys Acta 750: 200-202

3. Farese RV, Sabir MA, Larson RE (1981) Adrenocorticotropin and adenosine 3'5'-monophosphate stimulate de novo synthesis of adrenal phosphatidic acid by a cycloheximide-sensitive, $\mathrm{Ca}^{+-}$-dependent mechanism. Endocrinology 109: 1895-1901

4. Farese RV, Larson RE, Sabir MA, Gomez-Sanchez C (1981) Effects of angiotensin-II and potassium on phospholipid metabolism in the adrenal zona glomerulosa. J Biol Chem 256: 11093-11097

5. Tolbert EM, White AC, Aspry K, Cutts J, Fain JN (1980) Stimulation of vasopression and alpha-catecholamines of phosphatidylinositol formation in isolated rat liver parenchymal cells. $J$ Biol Chem 255: 19381944

6. Lowitt S, Farese R, Sabir M, Root AW (1982) Rat Leydig cell phospholipids are increased by $\mathrm{LH}$ and 8-bromo-cyclic AMP.
Proceedings of the 64th Annual Meeting of the Endocrine Society, San Francisco, CA, p 317 (Abstract)

7. Farese RV, Bidot-Lopez P, Sabir A, Smith JS, Schinbeckler B, Larson R (1980) Parathyroid hormone acutely increases polyphosphoinositides of the rabbit kidney cortex by a cycloheximide-sensitive process. J Clin Invest 65: 1523-1526

8. Farese RV, Farese RV Jr, Sabir MA, Larson RE, Trudeau WL III, Dee B (1984) The mechanism of action of insulin on phospholipid metabolism in rat adipose tissue. Requirement for protein synthesis and a carbohydrate source, and relationship to activation of pyruvate dehydrogenase. Diabetes 33: 648-655

9. Niggli V, Adunyah ES, Carafoli E (1981) Acidic phospholipids, unsaturated fatty acis, and limited proteolysis mimic the effect of calmodulin on the purified erythrocyte $\mathrm{Ca}^{2+}$-ATPase. J Biol Chem 256: 8588-8592

10. Warren GB, Hously MD, Metcalfe JC, Birdsall NJM (1975) Cholesterol is excluded from the phospholipid annulus surrounding an active calcium transport protein. Nature 255: 684-687

11. Stekhoven FS, Bonting SL (1981) Transport adenosine triphosphatases: properties and functions. Physiol Rev 61: 1-77

12. Levy J, Gavin JR III, Fausto A, Gingerich R, Avioli LV (1984) Impaired insulin action in non-insulin-dependent diabetic rats. Diabetes 33: 901-906

13. Levy J, Gavin JR III, Karl IE (1986) Decreased insulin sensitivity in epitrochlearis musclc (EM) from non-insulin-dependent diabetic (NIDD) rats. Diabetes 35: 28 A (Abstract)

14. Bonner-Weir S, Trent DF, Honey RN, Weir GC (1981) Responses of neonatal rat islets to streptozotocin. Limited $\beta$-cell regeneration and hyperglycemia. Diabetes 30: 64-69

15. Portha B, Picon L, Rosselin G (1979) Chemical diabetes in the adult rat as the spontaneous evolution of neonatal diabetes. Diabetologia 17: 371-377

16. Levy J, Gavin JR III, Hammerman MR, Avioli LV (1986) $\left(\mathrm{Ca}^{2+}+\mathrm{Mg}^{2+}\right)$-ATPase activity in kidney basolateral membrane in non-insulin-dependent diabetic rats: effect of insulin. Diabetes 35: 899-905

17. Levy J, Gavin JR III, Morimoto S, Hammerman MR, Avioli LV (1986) Hormonal regulation of $\left(\mathrm{Ca}^{2+}+\mathrm{Mg}^{2+}\right)$-ATPase activity in canine renal basolateral membrane. Endocrinology 119: 2405-2411

18. Levy J, Teitelbaum SL, Gavin JR III, Fausto A, Kurose H, Avioli LV (1985) Bone calcification and calcium homestasis in rats with non-insulin-dependent diabetes induced by streptozotocin. Diabetes 34: 365-372

19. Sacktor B, Rosenbloom IL, Liang CT, Cheng L (1981) Sodium gradient and sodium plus potassium gradient-dependent L-glutamate uptake in renal basolateral membrane vesicles. J Membr Biol $60: 63-71$

20. Windus DW, Cohn DE, Klahr S, Hammerman MR (1981) Glutamine transport in renal basolateral vesicles from dogs with metabolic acidosis. Am J Physiol 246: F78-F86

21. Tsushima T, Friesen HG (1973) Radioreceptor assay for growth hormone. J Clin Endocrinol Metab 37: 334-337

22. Lowry OH, Rosebrough NJ, Farr AL, Randall RJ (1951) Protein measurement with the Folin phenol reagent. J Biol Chem 193: 265-275

23. Kadish AH, Little RL, Stemberger JC (1968) A new and rapid method for the determination of glucose by measurement of rate of oxygen consumption. Clin Chem 14: 116 131

24. Morgan CR, Lazarow A (1963) Immunoassay of insulin two-antibody systems: plasma insulin levels of normal subdiabetic and diabetic rats. Diabetes 12: 115-122

25. Bligh EG, Dyer WJ (1959) A rapid method of total lipid extraction and purification. Can J Biochem Physiol 37: 911-917

26. Thomas AP, Williamson JR (1983) Effects of insulin on phenylephrine-induced activation of phosphorylase and phosphoinositol turnover in isolated hepatocytes. J Biol Chem 258: 1411-1414

27. Bartlett GR (1959) Phosphorus assay in column chromatography. J Biol Chem 234: 466468

28. Hammerman MR, Gavin JR III (1984) Insulin-stimulated phos- 
phorylation and insulin binding in canine renal basolateral membranes. Am J Physiol 247: F408-F417

29. Jacobs S, Hazum E, Cuatrecasas P (1980) The subunit structure of rat liver insulin receptor. Antibodies directed against the insulin binding subunit. J Biol Chem 255: 6937-6940

30. Talor Z, Fmmanuel DS, Katz AI (1982) Insulin binding and degradation by luminal and basolateral tubular membranes from rabbit kidney. J Clin Invest 69: 1136-1146

31. Bishop JS, Steele R, Altszuler N, Dunn A, Bjerknes C, DeBodo RC (1965) Effects of insulin on liver glycogen synthesis and breakdown in the dog. Am J Physiol 208: 307-316

32. Hope-Gill HF, Nanada V (1979) Stimulation of calcium ATPase by insulin, glucagon, cyclic AMP and cyclic GMP in Triton X100 extracts of purified rat liver plasma membrane. Horm Metab Res 11: 698-700

33. Krett NL, Heaton JH, Gelehrter TD (1983) Insulin resistance in $\mathrm{H}-34$ rat hepatoma cells is mediated by post-receptor mechanisms. Mol Cell Endocrinol 32: 91-100

34. DeFronzo RA, Cooke CR, Andres R, Faloona GR, Davis PJ (1975) The effect of insulin on renal handling of sodium, potassium, calcium and phosphate in man. J Clin Invest 55: 845-855

35. Sauerheber RD, Kuhn CE, Hyslop PA (1984) Membrane structural/functional properties of adipocytes from normal and streptozotocin-diabetic rats. Diabetes 33: 258-265

36. Kalofoutis A, Lekakis J (1981) Changes of platelet phospholipids in diabetes mellitus. Diabetologia 21: 540-543

37. Verkleij AJ, Zwaal RFA, Roelofsen B, Comfurius P, Kastelign D, van Deenen LLM (1973) The asymmetric distribution of phospholipids in the human red cell membrane. A combined study using phospholipases and freeze-etch electron microscopy. Biochem Biophys Acta 323: 178-193

38. McMillan DE (1983) Insulin, diabetes, and the cell membrane: an hypothesis. Diabetologia 24: 308-310

39. Carafoli F (1984) Calcium-transporting systems of plasma membranes, with special attention to their regulation. In: Greengard P, Robinson GA, Paoletti RP, Nicosia SN (eds) Advances in cyclic nucleotide and protein phosphorylation research, vol 17. Raven Press, New York, pp 543-549
40. Wali RK, Jaffe S, Kumar D, Kalra VK (1988) Alterations in organization of phospholipids in erythrocytes as factor in adherence to endothelial cells in diabetes mellitus. Diabetes 37: 104-111

41. Farese RV, Davis JS, Barnes DE, Standaert ML, Babischkin JS, Hock R, Rosic NK, Pollet RJ (1985) The de novo phospholipid effect of insulin is associated with increases in diacylglycerol, but not inositol phosphates or cytosolic $\mathrm{Ca}^{2+}$. Biochem J 231: 269-278

42. Farese RV, Konda TS, Davis JS, Standaert ML, Pollet RJ, Cooper DR (1987) Insulin rapidly increases diacylglycerol by activating de novo phosphatidic acid synthesis. Science 136: 586 - 589

43. Chalifour RJ, Kanfer JN (1980) Microsomal phospholipase D of rat brain and lung tissues. Biochem Biophys Res Commun 96: 742-747

44. Levy J, Avioli LV, Roberts ML, Gavin JR III (1986) $\left(\mathrm{Na}^{+}+\mathrm{K}^{-}\right)$-ATPase activity in kidney basolateral membranes of non-insulin-dependent diabetic rats. Biochem Biophys Res Commun 139: 1313-1319

45. Levy J, Grunberger G, Gavin JR III (1987) Loss of regulatory effect of insulin on membrane $\left(\mathrm{Ca}^{2+}+\mathrm{Mg}^{2} \cdot\right)$-ATPase from noninsulin-dependent (NIDD) diabetic rats is reversed by food restriction but not by insulin treatment. Clin Res 35: 862A (Abstract)

46. Schaefer W, Prießen J, Mannhold R, Gries AF (1987) $\mathrm{Ca}^{2 \cdot}+\mathrm{Mg}^{2}$-ATPase activity of human red blood cells in healthy and diabctic volunteers. Klin Wochenschr 65: 17-21

Received: 24 August 1987

and in revised form: 12 February 1988

Dr. J. Levy

University Health Center

4th Floor, POD $\mathrm{H}$

4201 St. Antoine

Detroit, MI 48201

USA 